2. A Special Committee may draw up reports on questious relating to matters within its province. Such reports shall be signed by those members of the Special Committee who approve of their contents, and shall be then forwarded to the General Committee. The General Committee may (a) recommend such reports to the Council for publication as reports of one or more Special Committees, or $(b)$ adopt them, with the consent of the Special Committee or Committees, and recommend them to the Council for publication as reports of the General Committee, or $(c)$ refer them back to the Special Committee or Committees.

3. Reports recommended to the Council for publication (as above) shall be published by the Council unless the Council cunsiders that it is inexpedient to do so for financial reasons.

\title{
EXHIBITION OF MODELS AT THE INTERNATIONAL CONGRESS.
}

To the Editor of The Mathematical Gazette. INTERNATIONAL CONGRESS OF MATHEMATICTANS.

\author{
January 20th, 1912.
}

Dear Sir,--I regret to say that there has been very little response to the notice which was inserted in the last number of the Gazette respecting the exhibition of models, apparatus, books, etc., which the Association is organising in connection with the International Congress. The committee charged with the organisation of the exhibition has gone further into the matter, and $I$ am able to give a few details concerning the various sections in which it is proposed to arrange the exhibition. These may be classified as follows:

1. Models and Diagrams. In this section it is proposed to make a collection of models, made by the pupil or teacher, for use or illustration in the teaching of mathematics or mechanics. The committee desire that as far as possible these should not be mere isolated models, but should illustrate some connerted piece of work. An explanatory paper should accompany the models, and it is proposed that these shall be printed for distribution to visitors. Offers of exhibits in this section should be sent as soon as possible to P. Abbott, 5 West View, Highgate Hill, N.

2. Exhibition of Work. The committee think that it would prove of great interest if it could be possible to show the actual note books, or work books of the pupils where some special scheme of work is being carried out or some experiment is being made in mathematical teaching. It is not intended that mere show books should be exhibited, but genuine specimens of class work. Offers from public schools and secondary schools should be sent to F. Boon, Dulwich College.

3. Exhibition of Mathematical Text-books.

4. Exhibition of Mathematical and Mechanical Apparatus (from makers). The organisation of these is being undertaken by Mr. Abbott.

5. Specimen Syllabus. It was felt by the committee that visitors to the congress would be interested in syllabuses of mathematical teaching in those schools where attempts are being made to develop the teaching on modern lines. Offers of help will be welcomed.

There are two or three other directions in which the committee hope to make arrangements for exhibits, but I trust that what I have written may serve to remind members of the necessity for taking the matter in hand at once. Suggestions will be welcomed by the committee. I am,

Yours faithfully,

5 WEST ViEW, Highgate Hill, N. P. Aввотт, Hon. Sec. of the Committee is 